\title{
54. Insect Transmission of Potato Witches' Broom in Japan
}

\author{
By Teikichi Fukushi, Eishiro Shikata, Hiroyuki Shioda, \\ Eikichi SekiYama, Ichiro TanaKa, Nobuyuki Oshima, \\ and Yoshiaki NisHIo
}

(Comm. by S. Kusano, M.J.A., April 12, 1955)

Potato witches' broom was noticed for the first time in 1932 at Assabu-Village in the south-western part of Hokkaido; since then it has appeared occasionally in potato fields at several places in this island. Because of its rare and irregular occurrence it has been considered to be a disease of minor importance. During the summer of 1950, however, fairly numerous potato plants were affected with witches' broom in the Iburi Potato Foundation Seed Farm of the Ministry of Agriculture; furthermore simultaneous outbreaks of this disease were reported from several localities where the affected seed potatoes had been distributed among seed potato growers. Circumstantial evidence seemed to suggest that the infection of potato witches' broom frequently takes place by means of certain insect vectors in the potato fields of the above-mentioned Potato Foundation Seed Farm. Transmission experiments were accordingly started by the writers in that year. Seven species of leafhoppers and 3 species of aphids were tested for their ability to transmit the virus before finding the vector, Ophiola flavopicta (Ishihara). Some of the leafhoppers tested were collected on wild plants and weeds growing in areas adjacent to the potato fields. The leafhopper, Ophiola flavopicta (Omaniella flavopicta Ishihara) was found in 1952 to be more or less abundant in clovers growing in the plots close by the potato fields in the Potato Foundation Seed Farm. Subsequently it was found that some individuals of the leafhopper in question would migrate into the potato fields; on the other hand attempts to maintain the leafhoppers on potato plants and red clovers in insect cages were successful, numerous nymphs emerging on these plants. During 1953 it was found that some alsike and red clover plants were affected with a witches' broom, in the neighborhood of the potato field where potato witches' broom appeared. Nymphs of the leafhopper under consideration were quite abundant in this clover growing plot.

It was attempted to transmit potato witches' broom and clover witches' broom to potato seedlings by the agency of the leafhopper, Ophiola flavopicta. Non-viruliferous leafhoppers, which had been reared on healthy potato and clover plants, were fed on witches' 
broom-diseased potato or red clover plants for 4-15 days and subsequently transferred to healthy potato seedling plants in insect cages and allowed to remain there for 2-48 days, mostly 3 to 17 days. Six out of 23 potato seedlings thus inoculated with potato witches' broom contracted the disease and 3 of 10 potato plants likewise inoculated with red clover witches' broom virus showed typical symptoms of potato witches' broom as indicated in the following table. The incubation period of the virus in a potato plant was remarkably long, ranging from 39-49 days to 98-102 days. That period was still longer in cases when the disease made its appearance on the sprouts from tubers which had been produced by the infected plants.

During 1954 an investigation was undertaken to transmit the witches' broom virus by means of the leafhopper from naturally infected potato, red clover, and Vicia unijuga plants to healthy potato, clovers, and Vicia unijuga plants. Vicia unijuga plants affected with a witches' broom were frequently seen in the areas close by the potato fields in the Potato Foundation Seed Farm and it seemed highly probable that the disease was induced by the virus of potato witches' broom. The results of experiments are shown in the following table.

Results of transmission experiments with potato witches' broom by means of the leafhopper, Ophiola flavopicta

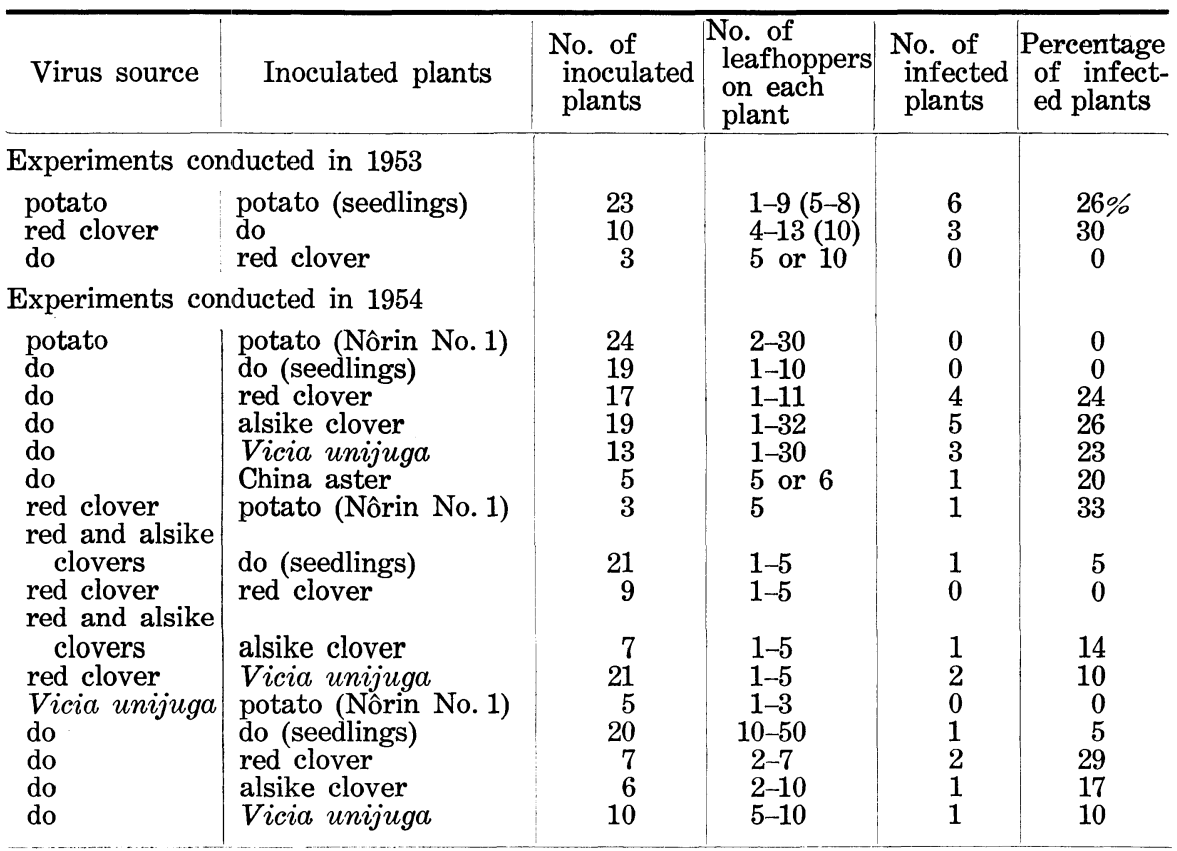


It is evident from the experimental results that the leafhopper, Ophiola flavopicta (Ishihara) is capable of transmitting the virus of witches' broom from affected potato, clovers, and Vicia unijuga plants to healthy plants and that the witches' broom of these plants found under natural conditions appears to be caused by one and the same virus. It seems highly probable that the virus hibernates within the roots of affected clovers or Vicia unijuga plants and is disseminated to potato fields by means of infective leafhoppers. As shown in the above table, a comparatively low percentage of infection was obtained in the transmission experiments, which may account for the relatively rare occurrence of the disease in potato fields. 